\title{
Pengelolaan Hulu Sub-DAS Logawa dalam Perda Penataan Ruang Kabupaten Banyumas
}

\author{
Upstream Watersheeds Management of Logawa Sub-Watersheed In \\ Banyumas Regency Regional Spatial Planning Regulation
}

\section{Budi Prabowo As'attohara ${ }^{1}$}

Program Studi Magister Ilmu Lingkungan, Universitas Jenderal Soedirman, Purwokerto, Indonesia

\section{Imam Santosa}

Fakultas IImu Sosial dan IImu Politik, Universitas Jenderal Soedirman, Purwokerto, Indonesia

\section{Tamad Tamad}

Fakultas Pertanian, Universitas Jenderal Soedirman, Purwokerto, Indonesia

Artikel Masuk : 22 Juli 2021

Artikel Diterima : 22 November 2021

Tersedia Online : 31 Desember 2021

\begin{abstract}
Abstrak: Degradasi hulu daerah aliran sungai (DAS) di Pulau Jawa mengkhawatirkan dan memicu perubahan terhadap karakter hidrologi DAS secara keseluruhan serta jasa ekosistemnya. Menjaga kelestarian DAS dari degradasi pada masa yang akan datang dapat dimulai dengan merumuskan kebijakan serta merancang manajemen pengelolaan yang tepat. Sub-DAS Logawa bukan merupakan DAS kritis, namun wilayah hulunya merupakan bagian dari lereng pegunungan dengan curah hujan sangat tinggi. Hulu Sub-DAS Logawa berperan penting dalam menyerap air hujan dan menyediakan cadangan air bawah tanah serta aliran air permukaan bagi Kota Purwokerto. Penting untuk mengkaji aturan pemerintah yang berkaitan dengan pengelolaannya, agar dapat diketahui sampai sejauh mana kebijakan dan tata kelolanya saat ini. Penelitian ini bertujuan menganalisis kebijakan penataan ruang dan wilayah tingkat kabupaten yang berkaitan dengan pengelolaan hulu Sub-DAS Logawa. Saat penelitian ini dilakukan Peraturan Daerah Nomor 10 Tahun 2011 tentang Rencana Tata Ruang Wilayah Kabupaten Banyumas merupakan satu-satunya peraturan daerah Kabupaten Banyumas yang dapat mengatur pengelolaan wilayah hulu Sub-DAS Logawa. Peraturan tata ruang wilayah tersebut menetapkan kawasan hulu Sub-DAS Logawa sebagai kawasan lindung, kawasan pengembangan pembangkit tenaga listrik dan wisata sungai, namun tidak secara khusus mengatur batasan minimal tutupan lahan hutan bagi kawasan lindung. Perda ini belum cukup layak bagi upaya menjaga kelestarian hulu Sub-DAS Logawa pada masa yang akan datang, serta bagi upaya penata-kelolaan hulu Sub-DAS Logawa sebagai sebuah ekosistem hulu DAS.
\end{abstract}

Kata Kunci: hulu DAS; kebijakan tata ruang wilayah kabupaten; pengelolaan DAS; Sub-DAS Logawa

Abstract: The watersheds upstream degradation in Java, is alarming and trigger changes to overall hydrological character of watersheds and its ecosystem services. Maintaining healthy

\footnotetext{
${ }^{1}$ Korespondensi Penulis: Program Studi Magister Ilmu Lingkungan, Universitas Jenderal Soedirman, Purwokerto, Indonesia Email: asattohara@gmail.com
} 


\section{Pengelolaan Hulu Sub-DAS Logawa dalam Perda Penataan Ruang Kabupaten Banyumas}

watershed from future degradation can be initiated by a means formulating policies and designing appropriate management plan. The Logawa sub-watershed is not a critical watershed, nonetheless the upstream is part of mountain slope with very high annual rainfall. The headwater of Logawa sub-watershed plays an important role in catching annual rainfall and provide the underground and surface water supply for Kota Purwokerto. It is important to study the government's regulation related on its management, to determine the current management policy. This study aims to analyze the district level spatial and regional planning regulation related to the upstream management of the Logawa Sub-watershed. When this study was conducted, Local Government Regulation Number 10 year of 2011, concerning regional spatial planning was the only regulation of the Banyumas district that could regulate management of the upstream zone of Logawa sub-watersheed. This spatial regulation assign the upstream area of the Logawa sub-watershed as conservation zone, as well as the development area for generating electricity and river tourism, but does not specifically stipulate a minimum conservation zone forest land cover. The regulation is not sufficient for managing healthyness of the upstream Logawa Sub-watershed for the future, as well as to manage the upstream zone of the Logawa Sub-watershed as an upstream watershed ecosystem.

Keywords: Logawa sub-watershed; regional spatial planning regulation; upstream watershed; watershed management

\section{Pendahuluan}

Jumlah penduduk Indonesia yang semakin bertambah membutuhkan ketersediaan air berjumlah besar bagi berbagai keperluan. Penyedia air bersih merupakan bentuk ecosystem service sungai yang paling utama. Kualitas dan kuantitas air sungai berkaitan erat dengan kondisi ekosistem sebuah DAS pada bagian hulu. Menurut Nugroho (2009), kondisi hulu DAS di Pulau Jawa mengalami degradasi yang berat dan telah berubah watak hidrologinya. Nk et al. (2013) menyatakan bahwa Pulau Jawa mempunyai angka Indeks Pemanfaatan Air (IPA) sebesar 54\%, artinya Pulau Jawa telah masuk dalam fase kritis ringan dalam memanfaatkan cadangan airnya. Neraca air di Pulau Jawa menunjukkan dapat terjadi kelangkaan air pada beberapa bulan di musim kemarau.

Menurut laman publikasi Sekretariat Kabinet Republik Indonesia, 12 November 2018, kondisi DAS di Indonesia menunjukkan peningkatan kerusakan setiap tahunnya. Pada tahun 1984 terdapat 22 DAS dalam keadaan kritis dengan luas 9.699.000 ha. Tahun 1994 meningkat menjadi 39 DAS kritis dengan luas lahan kritis mencapai 12.517.632 ha. Pada tahun 2000 DAS kritis di Indonesia berjumlah 42, dengan luas lahan kritis mencapai 23.714.000 ha. Pada akhir tahun 2018 sejumlah 108 DAS dalam status kritis, dari total sejumlah 2.145 DAS yang statusnya harus dipulihkan.

Peraturan Pemerintah Nomor 37 tahun 2012 tentang Pengelolaan DAS memberi kesempatan untuk mengatur pengelolaan DAS melalui peraturan daerah (Pemerintah Republik Indonesia, 2012). Setiap kabupaten maupun provinsi dapat membuat peraturan daerah yang mengatur pengelolaan DAS. Peran pemerintah provinsi adalah memberikan pertimbangan teknis bagi rencana pengelolaan dan penyelenggaraan pengelolaan DAS dalam lingkup provinsi. Pemerintah daerah kabupaten atau kota berperan dalam memberikan pertimbangan-pertimbangan teknis tentang penyusunan rencana pengelolaan dan penyelenggaraan pengelolaan DAS yang berada dalam wilayah kabupaten atau kota yang bersangkutan.

Provinsi Jawa Tengah mengatur pengelolaan DAS dengan Perda Nomor 15 tahun 2014 tentang Pengelolaan Daerah Aliran Sungai (Pemerintah Provinsi Jawa Tengah, 2014). Dalam peraturan daerah tersebut menyatakan bahwa 12 DAS berstatus dipertahankan daya dukungnya, 18 DAS lainnya berada dalam kondisi kritis dan harus dipulihkan daya 
dukungnya. DAS Serayu merupakan salah satu DAS di Jawa Tengah yang berstatus harus dipulihkan daya dukungnya. Sub-DAS Logawa berhilir pada DAS Serayu, dalam arti lain Sub-DAS Logawa adalah aliran tributary dari DAS Serayu. Sub-Das Logawa sejak hulu hingga hilir berada dalam wilayah Kabupaten Banyumas. Status Sub-DAS Logawa tidak termasuk dalam DAS yang harus dipulihkan daya dukungnya, namun dalam dokumen Status Lingkungan Hidup Kabupaten Banyumas tahun 2009 (Dinas Lingkungan Hidup Kabupaten Banyumas, 2009), disebutkan bahwa Sungai Logawa (Sub-DAS Logawa) sudah masuk dalam daftar sungai yang mengalami penurunan mutu kualitas airnya (Dinas Lingkungan Hidup Kabupaten Banyumas, 2009).

Hulu Sub-DAS Logawa berawal dari aliran permukaan dalam kawasan hutan di wilayah lereng selatan Gunung Slamet. Wilayah ini merupakan perpaduan wilayah hutan, perkebunan, persawahan serta pemukiman penduduk yang menyumbangkan aliran air permukaan melewati Kota Purwokerto sebagai Sungai Logawa. Penerima manfaat dari lestarinya kondisi ekosistem hulu Sub-DAS Logawa tidak hanya masyarakat pedesaan pada wilayah hulu DAS saja. Wilayah kota Purwokerto juga mendapatkan manfaat atas lestarinya hulu Sub-DAS Logawa dalam bentuk aliran permukaan dan aliran air bawah tanah sebagai sumber air bersih. Ekosistem DAS adalah sumber daya alam milik bersama, common pool resourcess (CPR), setiap pihak mempunyai akses untuk mengelola demi kemajuan dan kesejahteraan bersama.

Pengelolaan DAS yang baik diperlukan agar terjaga keseimbangan pemanfaatan dan keberlanjutan daya dukungnya untuk masa yang akan datang. Hal ini penting karena ekosistem DAS bersifat terbuka dan dinamis. Sifat terbuka dan dinamis DAS ini dimulai dari mata air dan kondisi hutan pada wilayah hulu, pertemuan antar berbagai aliran permukaan, area pemanfaatan, hingga wilayah hilir. Karakteristik DAS yang khas tersebut sejak mula pendekatan DAS diperkenalkan telah disampaikan oleh Likens \& Bormann (1974) sebagai hubungan terpenting antara ekosistem air tawar dan terestrial dalam biosfer kita.

Beberapa penelitian berikut telah mempelajari aliran Sub-DAS Logawa pada seluruh alirannya, maupun fokus pada wilayah hulu. Lestari (2004) meneliti seluruh aliran tributary Sub-DAS Logawa dengan mengajukan spesies ikan sebagai bio-indikator kondisi Sub-DAS Logawa. Dari parameter kondisi air dan kondisi komunitas ikan air tawarnya, kondisi SubDAS Logawa dikategorikan kurang baik. Disebutkan aliran air sungai Logawa termasuk dalam kategori tercemar bahan organik (Lestari, 2004). Besarnya potensi pembangkitan tenaga listrik dari aliran air permukaan Sub-DAS Logawa disampaikan oleh Wicaksono et al. (2013) dan Wijaya et al. (2012). Dua laporan ini menyajikan potensi Sungai Logawa sebagai pembangkit tenaga listrik dan simulasi sampel data kelayakan rencana pembangunan Pembangkit Listrik Tenaga Mikro Hidro (PLTMH) pada aliran Sub-DAS Logawa. Debit aliran permukaan Sub-Das Logawa disimpulkan layak untuk menghasilkan keuntungan secara ekonomis bagi pembangunan PLTMH di Sungai Logawa.

Selain berkaitan dengan keberadaan aliran air permukaan, kajian atas keberadaan hutan rakyat di hulu Sub-DAS Logawa dilakukan oleh (Ethika et al., 2014a, 2014b; Ethika, 2015). Ethika dalam publikasinya tahun 2014 mengulas hutan rakyat dari aspek lingkungan, aspek ekonomi dan aspek sosial. Hutan rakyat ini keberadaannya banyak tersebar di hulu Sub-DAS Logawa, terutama pada wilayah dengan akses yang terbatas bagi masyarakat selain petani hutan. Tahun berikutnya Ethika (2015) melaporkan tentang rumusan strategi pembangunan hutan rakyat tersebut, kekhasan karakter hutan rakyat, peran serta masyarakat petani, produktivitasnya, serta peranannya pada pemanfaatan lahan kritis di hulu Sub-DAS Logawa.

Aspek manajemen aset kelembagaan Sub-DAS Logawa dikaji oleh Irawadi (2014) dengan melakukan inventarisasi aset Sub-DAS Logawa, kepemilikan, kewenangan pengelolaan. Batasan asetnya adalah pada aset kelembagaan (intangible asset) sumber daya air, berdasarkan Undang-Undang Nomor 7 Tahun 2004 tentang Sumber Daya Air 
(Pemerintah Republik Indonesia, 2004). Sub-DAS Logawa, yang terdiri dari berbagai aset dan parapihak pengelolanya, dianalisis dengan melihat kemanfaatan dan berdasarkan kesepakatan parapihak. Kemudian bentuk pelaksanaan manajemen berbagai aset kelembagaan Sub-DAS Logawa tersebut ditampilkan dan dianalisis. Suwarno et al. (2017) mengkaji bahwa hulu Sub-DAS Logawa juga memiliki potensi erosi dan ancaman bencana longsor lahan. Penelitian ini memanfaatkan Sistem Informasi Geografis, yang di dalamnya diolah peta penggunaan lahan, kemiringan lereng, jenis tanah dan curah hujan. Penelitian ini mengklasifikasi seluruh Sub-DAS Logawa dalam lima kategori ancaman bahaya erosi, wilayah hulu Sub-DAS Logawa masuk dalam kelas risiko bahaya erosi tinggi.

Mengingat seluruh aliran Sub-DAS Logawa berada dalam lingkup wilayah Kabupaten Banyumas, berbagai penelitian tersebut belum mempelajari regulasi dan kebijakan pemerintah daerah Kabupaten Banyumas dalam melakukan penata-kelolaan hulu Sub-DAS Logawa. Saat penelitian ini dilakukan tidak ada peraturan daerah di Kabupaten Banyumas yang secara khusus mengatur pengelolaan DAS. Peraturan daerah kabupaten yang paling relevan menjadi rujukan dalam pengelolaan DAS di Kabupaten Banyumas saat ini adalah Peraturan Daerah Nomor 10 Tahun 2011 tentang Rencana Tata Ruang Wilayah Kabupaten Banyumas Periode 2011-2031 (Pemerintah Kabupaten Banyumas, 2011).

Menurut Peraturan Menteri Kehutanan Nomor 39 Tahun 2009 tentang Pedoman Penyusunan Rencana Pengelolaan DAS Terpadu, Kementerian Pekerjaan Umum berperan melakukan pengelolaan sumber daya air dan tata ruang (Kementerian Kehutanan, 2009). Dalam konteks hulu Sub-DAS Logawa, Perda Nomor 10 tahun 2011 Tentang Tata Ruang Wilayah Kabupaten Banyumas 2011-2031 perlu dipelajari sejauh mana perannya dalam ikut mengatur pengelolaan Sub-DAS Logawa. Hal ini penting, karena peraturan daerah tersebut satu-satunya Perda di Kabupaten Banyumas yang dapat menjadi rujukan pengelolaan hulu Sub-DAS Logawa.

Interaksi antara peraturan daerah tata ruang wilayah pada sebuah hulu DAS tidak selalu berdampak baik pada hulu DAS. Pelajaran berharga dapat disimak pada laporan Susanti et al. (2020) yang menggambarkan relasi perubahan tata ruang wilayah provinsi Jawa Tengah 2009-2029 dengan kerusakan hulu DAS Serayu. Peraturan Daerah Kabupaten Banyumas Nomor 10 Tahun 2011 tentang Rencana Tata Ruang Wilayah 2011-2031 ini dapat mempengaruhi pengelolaan DAS di Kabupaten Banyumas, khususnya pada hulu Sub-DAS Logawa. Perda DAS Kabupaten Banjarnegara dapat menjadi sebuah pembanding untuk menilai kebijakan pengelolaan DAS lewat sebuah perda spesifik yang mengatur DAS. Penelitian ini bertujuan menganalisis kebijakan penataan ruang dan wilayah tingkat kabupaten yang berkaitan dengan pengelolaan hulu Sub-DAS Logawa. Penelitian ini menganalisis kebijakan penatakelolaan hulu Sub-DAS Logawa yang paling aktual dalam Perda Nomor 10 Tahun 2011, tentang Rencana Tata Ruang Wilayah Kabupaten Banyumas periode 2011-2031.

\section{Metode Penelitian}

Wilayah hulu Sub-DAS Logawa sebagai objek studi adalah Desa Baseh, Kecamatan Kedungbanteng dan Desa Sunyalangu, Kecamatan Karanglewas, Kabupaten Banyumas. Metode yang digunakan dalam penelitian ini adalah kualitatif-deskriptif dengan pendekatan yuridis normatif. Data yang digunakan dan diolah dalam penelitian adalah data sekunder berupa Perda Kabupaten Banyumas Nomor 10 Tahun 2011 tentang Rencana Tata Ruang Wilayah Kabupaten Banyumas periode 2011-2031, yang didapatkan dari Sekretariat Pemerintah Daerah Kabupaten Banyumas. Selain itu juga digunakan Perda Kabupaten Banjarnegara Nomor 4 Tahun 2013 tentang Pengelolaan Daerah aliran Sungai (Pemerintah Kabupaten Banjarnegara, 2013), sebagai pembanding. Data dalam penelitian dikumpulkan dengan menelaah masing-masing Perda dan mengkurasi informasi yang berkaitan dengan 
objek penelitian. Kurasi data yang dilakukan dalam penelitian ini meliputi aspek penatakelolaan DAS dan hulu DAS dalam dokumen RTRW Kabupaten Banyumas, serta dalam Perda pengelolaan DAS Kabupaten Banjarnegara.

Metode analisis yang digunakan dalam penelitian ini adalah analisis isi (content analysis). Peta yang disajikan bersumber dari dokumen Peta Tematik yang menjadi kesatuan dalam Perda RTRW Kabupaten Banyumas 2011-2031. Peta tersebut diolah menggunakan perangkat lunak Arc-GIS 10.3 untuk memudahkan memilih, memotong dan menyajikan kembali informasi keruangan yang sesuai dengan kebutuhan penelitian. Data lainnya didapatkan dari observasi wilayah penelitian serta laporan penelitian dan literatur yang berkaitan dengan hulu Sub-DAS Logawa.

\section{Hasil dan Pembahasan}

Regulasi penataan ruang wilayah Kabupaten Banyumas yang dapat mengatur hulu Sub-DAS Logawa ini ditelaah tahun 2021. Publikasi ini ditujukan untuk membuka ruang diskusi baru dalam melihat penata-kelolaan hulu Sub-DAS Logawa, dari aspek tata ruang wilayah. Peraturan Daerah Tata Ruang Wilayah Kabupaten Banyumas yang saat ini berlaku adalah Perda Nomor 10 tahun 2011, Rencana Tata Ruang dan Wilayah Kabupaten Banyumas untuk periode tahun 2011 hingga tahun 2031. Selanjutnya disebut sebagai Perda Nomor 10 tahun 2011 RTRW Kabupaten Banyumas.

Perda ini ditetapkan sebagai arahan kebijakan dan strategi pemanfaatan ruang dan wilayah Kabupaten Banyumas. Perda Nomor 10 tahun 2011 RTRW Kabupaten Banyumas terbagi menjadi 14 bab, memuat 117 pasal yang berisikan aturan dan ketentuan-ketentuan penataan ruang dan wilayah. Selain aturan dan ketentuan tersebut terdapat tabel indikasi program dan peta tematik yang menjadi satu kesatuan dengan dokumen perda. Lewat dokumen RTRW Kabupaten Banyumas 2011-2013 ini kebijakan dan penata-kelolaan hulu Sub-DAS Logawa saat ini dapat diamati.

\section{DAS dalam Aturan dan Ketentuan Penataan Ruang Wilayah RTRW Kabupaten Banyumas 2011- 2031}

Dokumen Perda Nomor 10 tahun 2011 RTRW Kabupaten Banyumas menggunakan beberapa terminologi berkaitan dengan sungai antara lain, DAS, sungai, aliran sungai dan sistem wilayah sungai. Istilah DAS disebutkan dalam ketentuan umum pada bagian definisi tentang Daerah Aliran Sungai (DAS). Terminologi DAS hanya digunakan pada penyebutan antara lain DAS Serayu, DAS Serayu-Bogowonto, DAS Ijo, DAS Cimeneng dan DAS Tipar. Perda Nomor 10 tahun 2011 RTRW Kabupaten Banyumas mengatur sungai dalam berbagai aspek antara lain sebagai berikut: Pertama, Pengembangan jaringan transportasi sungai sebagai pendukung sarana wisata, di dalamnya disebutkan DAS Serayu dan Sungai Logawa. Maksud dari pengembangan jaringan transportasi sungai ini adalah bagi pengembangan wisata sungai, prioritasnya adalah Sungai Serayu. Tidak ada penjelasan lain yang berkaitan dengan penyebutan Sungai Logawa serta berelasi dengan pengembangan jaringan transportasi sungai pada tabel indikasi program rencana tata ruang.

Kedua, sungai sebagai sistem jaringan sumber daya air. Di dalamnya disebutkan sistem wilayah sungai sebagai bagian dari irigasi dan penyedia air baku. Pada bagian ini disebutkan DAS Serayu, DAS Tipar, DAS Cimeneng, DAS Ijo dan Wilayah Sungai Citanduy. Tidak disebutkan Sub-Das Logawa dalam bagian pembahasan ini. Ketiga, kawasan perlindungan setempat, di dalamnya disebutkan kawasan sempadan sungai dan Ruang Terbuka Hijau (RTH). Pada bagian ini diatur secara spesifik batas pengelolaan dan infrastruktur sempadan sungai pada wilayah perkotaan. Keempat, tentang wisata sungai. Wisata sungai adalah wisata yang berada di sekitar aliran Sungai Serayu, dengan 


\section{Pengelolaan Hulu Sub-DAS Logawa dalam Perda Penataan Ruang Kabupaten Banyumas}

penyebutan wilayah kecamatan dan rencana pengembangannya. Pada bagian wisata sungai ini disebutkan Wisata Buatan Kali Logawa di Kecamatan Karanglewas. Namun, pada saat observasi dilakukan, satu-satunya wisata buatan yang berada pada sempadan hulu Sub-DAS Logawa, yaitu wahana wisata air Batur Agung di Desa Baseh telah lama berhenti beroperasi. Kelima, penyebutan sungai berkaitan dengan sistem jaringan sumber daya air, berupa normalisasi sungai di wilayah sungai Serayu. Bagian ini berkaitan dengan perbaikan embung dan konservasi situ, tidak berkaitan dengan Sub-DAS Logawa.

Keenam, pada bagian rencana pola ruang kawasan perlindungan setempat, diatur penataan sempadan dan penertiban bangunan pada sempadan sungai dan pengembangan $\mathrm{RTH}$, bagian ini spesifik untuk mengatur sungai dan badan air pada pada wilayah perkotaan. Ketujuh, bagian zonasi kawasan disekitar sistem jaringan sumber daya air. Dalam pembahasan ini diatur pemanfaatan ruang disepanjang sungai. Pemanfaatan ini diarahkan bagi kegiatan konservasi dan/atau kegiatan budidaya yang memiliki fungsi lindung. Lebih lanjut pada wilayah ini diperbolehkan mendirikan bangunan, namun harus memenuhi ketentuan garis sempadan sungai, sesuai ketentuan peraturan perundangundangan. Bangunan prasarana jalan, jembatan dan bangunan air lainnya di bawah atau di atas sungai diperbolehkan namun tidak boleh menimbulkan perubahan arus air yang merusak lingkungan dan tidak berpotensi menimbulkan pencemaran air. Bagian ini secara tegas melarang bangunan gedung di atas aliran sungai. Kedelapan, sungai berkaitan dengan aturan zonasi kawasan perlindungan setempat. Pada zonasi sempadan sungai tidak diperbolehkan semua kegiatan, namun ada pengecualian untuk hutan produksi, hutan produksi terbatas, hutan lindung, dan kegiatan pertanian bagi tanaman konservasi. Bagian ini memiliki relevansi dengan karakteristik objek penelitian yaitu hulu Sub-DAS Logawa, namun aturan zonasi kawasan perlindungan setempat ini bersifat umum dan dapat diterapkan pada wilayah manapun yang berstatus kawasan perlindungan setempat.

Dalam perda Nomor 10 tahun 2011 RTRW Kabupaten Banyumas pada aspek yang masih berkaitan dengan pemanfaatan sungai dan fungsi perlindungan serta konservasi sungai, diatur antara lain: Pertama, ada ketentuan umum pola ruang bagi kawasan lindung dan zonasi kawasan lindung setempat atau kawasan lindung lintas wilayah. Kedua, kawasan lindung lintas wilayah adalah sebagai kawasan yang memberikan perlindungan terhadap kawasan di bawahnya. Wilayah ini berupa kawasan resapan air di kecamatan Kedungbanteng dan berbagai kawasan resapan mata air lainnya. Terkait kawasan lindung dan fungsi resapan air, diatur dalam program indikasi sebagai program kerja yang bertujuan menjaga fungsi kawasan lindung. Disebutkan bahwa kawasan yang memiliki fungsi pemberi perlindungan terhadap kawasan di bawahnya, termasuk wilayah hulu Sungai. Berkaitan dengan aturan tentang hal ini, kawasan hulu Sub-DAS Logawa dinyatakan dalam Peta Kawasan Lindung RTRW pada Gambar 1, dengan warna hijau terang, artinya adalah kawasan yang melindungi kawasan di bawahnya. Pada bagian lain kemudian dijelaskan fungsi kawasan lindung lintas wilayah ini pada bagian ketentuan umum zonasi kawasan.

Ketiga, ketentuan umum zonasi Wilayah lindung ini boleh untuk kegiatan budidaya tanaman tahunan, agrowisata serta wisata alam, dengan tidak mengurangi fungsi lindung kawasan. Ada pengecualian bahwa kawasan ini boleh untuk hunian penduduk asli, namun dengan tidak merubah luas kawasan dan di bawah pengawasan ketat. Ada penegasan bahwa wilayah lindung lintas wilayah ini tidak boleh untuk budidaya tanaman semusim yang menghasilkan bahan pencemar serta budidaya dengan penutup lahan yang mengurangi infitrasi air kedalam tanah. Keempat, zona kawasan lindung yang dikelola masyarakat diperbolehkan melakukan pengambilan hasil hutan non kayu dan kegiatan kehutanan dan/atau penanaman tanaman konservasi. Dalam kawasan ini masyarakat boleh mendirikan hunian terbatas berupa bangunan rumah tinggal yang tidak perlu dilakukan perubahan bangunan, serta tidak berada pada lahan dengan kelerengan tinggi 
agar tidak mengganggu fungsi kawasan. Kegiatan yang dilarang dalam zona kawasan lindung yang dikelola masyarakat adalah, segala kegiatan yang berpotensi mengurangi tutupan lahan dari keberadaan tanaman keras. Tidak dijinkan di dalamnya dilakukan pengembangan budidaya, dengan lahan terbangun dan pengembangan pemukiman.

\section{Hulu Sub-DAS Logawa dalam Tabel Indikasi Program Pembangunan RTRW Kabupaten Banyumas 2011-2031}

Perda Nomor 10 tahun 2011 RTRW Kabupaten Banyumas dalam lampiran Tabel Indikasi Program RTRW 2011-2031 menyebutkan Sub-DAS Logawa dalam dua aspek yaitu (1) Sub-DAS Logawa disebutkan dalam proyeksi pengembangan jaringan transportasi sungai sebagai pendukung sarana wisata. Hal ini berkaitan dengan pengembangan wisata buatan yang berlokasi pada hulu Sub-DAS Logawa di Desa Baseh, Kecamatan Kedungbanteng. (2) Kecamatan Karanglewas disebutkan sebagai rencana lokasi pembangunan Pembangkit Listrik Tenaga Mikro Hidro (PLTMH). Lokasi indikasi program ini berada pada dua wilayah Kecamatan Kedungbanteng dan Karanglewas. Dalam wilayah penelitian saat ini telah beroperasi PLTMH yang memanfaatkan aliran permukaan SubDAS Logawa, yaitu PLTMH Logawa 1 di Desa Baseh, Kecamatan Kedungbanteng. Program ini merupakan bagian dari pengembangan sistem jaringan prasarana energi, dalam tabel indikasi program RTRW Kabupaten Banyumas 2011-2031.

Dengan menggunakan metode analisis isi untuk mempelajari Perda Nomor 10 Tahun 2011, terlihat sangat kuat pendekatan penataan ruang untuk mendorong pengembangan serta interaksi antar wilayah. Pendekatan penataan ruang dan wilayah memposisikan ekosistem DAS sebagai salah satu komponen lingkungan, di antara berbagai komponen lingkungan lain, yang layak dikembangkan bagi aset pembangunan. Isi Perda Nomor 10 tahun $2011 \mathrm{Kab}$, Banyumas yang paling erat berelasi dengan hulu Sub-Das Logawa adalah ketentuan tentang kawasan lindung setempat dan kawasan lindung lintas wilayah. Dengan adanya ketentuan dan pembagian fungsi ruang pada peta tematik kawasan lindung, maka wilayah penelitian berstatus sebagai kawasan lindung lintas wilayah. Perda RTRW Nomor 10 Tahun 2011 Kabupaten Banyumas sebagai kebijakan tata ruang dan pengembangan wilayah tidak menekankan wilayah hulu Sub-DAS Logawa sebagai ekosistem DAS secara khusus. Penekanan perda penataan ruang tersebut adalah tentang fungsi, pola dan peluang pengembangan serta interaksi antar wilayah. Perda ini adalah kebijakan untuk mengarahkan pembangunan di wilayah Kabupaten Banyumas, untuk memastikan adanya keterpaduan pembangunan antar sektor, daerah dan masyarakat, disebutkan dalam dokumen perda bagian ketentuan umum.

Sebagai pembanding, Perda Nomor 4 Tahun 2013 Kabupaten Banjarnegara tentang Pengelolaan DAS memuat beberapa poin penting berikut: Pertama, disebutkan secara eksplisit beberapa definisi turunan berkaitan dengan DAS antara lain pengelolaan DAS, klasifikasi DAS dan inventarisasi DAS serta status kelestarian DAS. Kedua, disebutkan maksud dan tujuan penetapan perda DAS. Ketiga, terdapat penjelasan tentang daya dukung DAS, maksud pengelolaan DAS, relasinya dengan kondisi DAS serta capaian pengelolaan DAS. Keempat, disebutkan perumusan dan identifikasi masalah DAS, pengelola DAS, penanggung jawab dan penyusunan rencana kelola serta pendanaannya. Kelima, ada monitoring dan evaluasi pengelolaan, serta indikator-indikator yang digunakan. Keenam, disebutkan strategi-strategi pengelolaan bagi tiap kondisi DAS. Ketujuh, ada hak dan kewajiban para pihak, serta peran serta dalam pengelolaan DAS. Pada bagian ini secara khusus disebutkan ambang batas penutupan lahan DAS dengan tegas berupa minimal 30\% lahan hutan. Kedelapan, ditetapkan tujuan dan sasaran pada masing masing bagian DAS, serta mekanisme pengawasannya. Sembilan, diatur mekanisme insentif dan dis-insentif berkaitan dengan pengelolaan DAS, serta ditetapkan 
pembinaan, pengawasan dan pemberdayaan masyarakat tempatan. Kesepuluh, disebutkan penyidikan, sangsi dan pidana terkait pengelolaan DAS.

DAS di wilayah kabupaten seringkali hanya diatur regulasi tata ruang wilayah. Menurut Saridewi et al. (2014) kebijakan pengelolaan DAS yang dilakukan oleh pemerintah selama ini berdasarkan pada tugas utama dan fungsi kementerian terkait. Peraturan Menteri Kehutanan Nomor 39 tahun 2009 tentang Pedoman Penyusunan Rencana Pengelolaan DAS Terpadu menjelaskan, kementerian pemangku pengelolaan DAS yaitu Kementerian Kehutanan, Kementerian Pekerjaan Umum dan kementerian Pertanian. Kementerian Kehutanan bertugas melakukan penataan hutan, pengelolaan kawasan konservasi dan rehabilitasi DAS. Kementerian Pekerjaan Umum melakukan pengelolaan sumber daya air dan tata ruang. Kementerian Pertanian berperan membina masyarakat dalam upaya pemanfaatan lahan pertanian serta irigasi.

Perda Nomor 10 Tahun 2011 Kabupaten Banyumas merupakan produk hukum turunan di tingkat kabupaten dengan perspektif penataan ruang dan wilayah. Merujuk Undang-undang Nomor 26 Tahun 2007 tentang Penataan Ruang, pasal 17 menyatakan untuk mencapai tujuan pelestarian lingkungan, dalam rencana tata ruang wilayah ditetapkan kawasan hutan paling sedikit 30\% dari luas DAS. Penjelasan undang-undang tersebut menyebutkan bahwa, penerapan luas tutupan hutan sebesar 30\% dapat disesuaikan dengan kondisi daerah aliran sungai pada tiap daerah. Dalam Perda Nomor 10 Tahun 2011 RTRW Kabupaten Banyumas tidak diulang atau ditegaskan kembali tujuan pelestarian lingkungan DAS dengan tutupan minimal 30\% lahan hutan tersebut. Dapat diartikan bahwa, kebijakan tata ruang Kabupaten Banyumas tidak memprioritaskan luas minimal tutupan lahan hutan tersebut, termasuk bagi hulu DAS. Namun demikian dalam Perda ini disebutkan juga bahwa kawasan perlindungan setempat melingkupi sempadan sungai dan sekitar mata air yang ditujukan untuk menjaga keseimbangan tata air.

\section{Status Hulu Sub-DAS Logawa Dalam Peta Tematik RTRW Kabupaten Banyumas 2011-2031}

Gambar 1 adalah olahan Peta Tematik Kawasan Lindung RTRW Kabupaten Banyumas 2011-2031 yang memperlihatkan hulu Sub-DAS Logawa berada dalam zonasi kawasan yang melindungi wilayah di bawahnya. Wilayah yang melindungi wilayah di bawahnya ini adalah wilayah dengan banyak mata air dan berstatus kawasan lindung. Dalam Peta Tematik Kawasan Hutan RTRW Kabupaten Banyumas 2011-2031 yaitu Gambar 2, disebutkan bahwa keberadaan hutan pada wilayah penelitian adalah Hutan Produksi Terbatas (HPT) Pt. Perhutani dan hutan rakyat. Peta Tematik Pola Ruang RTRW 2011-2013 wilayah penelitian yaitu Gambar 3, memperlihatkan kemiripan pola dengan Peta Kawasan Hutan. Wilayah Hutan Produksi terbatas dan hutan rakyat masih terlihat, namun sebagian wilayah yang tidak teridentifikasi fungsinya berwarna putih dalam Peta Kawasan Hutan (Gambar 2), dan Peta Pola Ruang (Gambar 3), teridentifikasi sebagai lahan tanaman perkebunan tahunan.

\section{Pembahasan}

DAS seperti diketahui bersama adalah sekumpulan sumber daya alam yang aksesnya bersifat terbuka. Perlu kiranya diperhatikan interaksi DAS dengan kebijakan pemerintah yang tak dapat dilepaskaitkan begitu saja. Solusi pengelolaan yang ditawarkan Elinor Ostrom adalah pengelolaan kolektif dan kerjasama antar pelaku pemanfaatan.

Ostrom (2008) berpendapat bahwa sumber daya alam yang bersifat terbuka dianggap milik umum, maka setiap orang dapat bersaing bebas memanfaatkan hingga kecenderungannya akan terjadi pemanfaatan berlebihan sampai hancur. Sebagian orang akan mendapatkan jumlah sumber daya berlebih, sedangkan sebagian orang lainnya akan kekurangan. Kegagalan pengelolaan sumber daya milik bersama, Common Pool 
Resourcess (CPR) akan berakibat pada pemanfaatan secara berlebihan, over-eksploitasi. Pemanfaatan sumber daya milik umum secara eksploitatif ini dapat bermuara pada terjadinya tragedy of the common. Ostrom (1990) menyajikan banyak fakta di negara berkembang bahwa privatisasi sumber daya alam membawa dampak lebih jauh pada permasalahan pengelolaan SDA yang semakin buruk. Berkaitan dengan konteks ekosistem hulu DAS, jika eksploitasi berlebihan terjadi maka dampaknya juga akan terjadi pada wilayah pemanfaatan, hingga wilayah hilir. Asumsi dasarnya kemudian adalah, jika ada kebijakan spesifik pengelolaan ekosistem hulu DAS yang khas, maka dapat mencegah terjadinya dampak besar pada wilayah pemanfatan dan hilir.

Persaingan pemanfaatan berbagai sumber daya alam dewasa ini begitu ketat. Kebijakan penataan ruang yang tidak tepat dapat berakibat pada eksploitasi berlebihan pada sebuah sumber daya alam milik bersama. Kondisi rusaknya hulu DAS Serayu dapat menjadi kerangka penghubung untuk memahami kemungkinan yang dapat terjadi pada hulu Sub-DAS Logawa. Susanti et al. (2020) menyatakan bahwa yang paling berpengaruh pada perubahan tutupan lahan hulu, dan kerusakan hulu DAS Serayu adalah perubahan kebijakan Rencana Tata Ruang Wilayah pada tingkat Provinsi Jawa Tengah. Perubahan RTRW Provinsi Jawa Tengah 2009-2029 mengubah kondisi hulu DAS Serayu lewat sektor pertanian dan pertambangan terbuka. Hal ini memperlihatkan bahwa perubahan kebijakan penataan ruang dapat berpotensi memunculkan kegiatan eksploitatif yang kemudian dapat berakibat secara langsung pada rusaknya ekosistem hulu DAS Serayu.

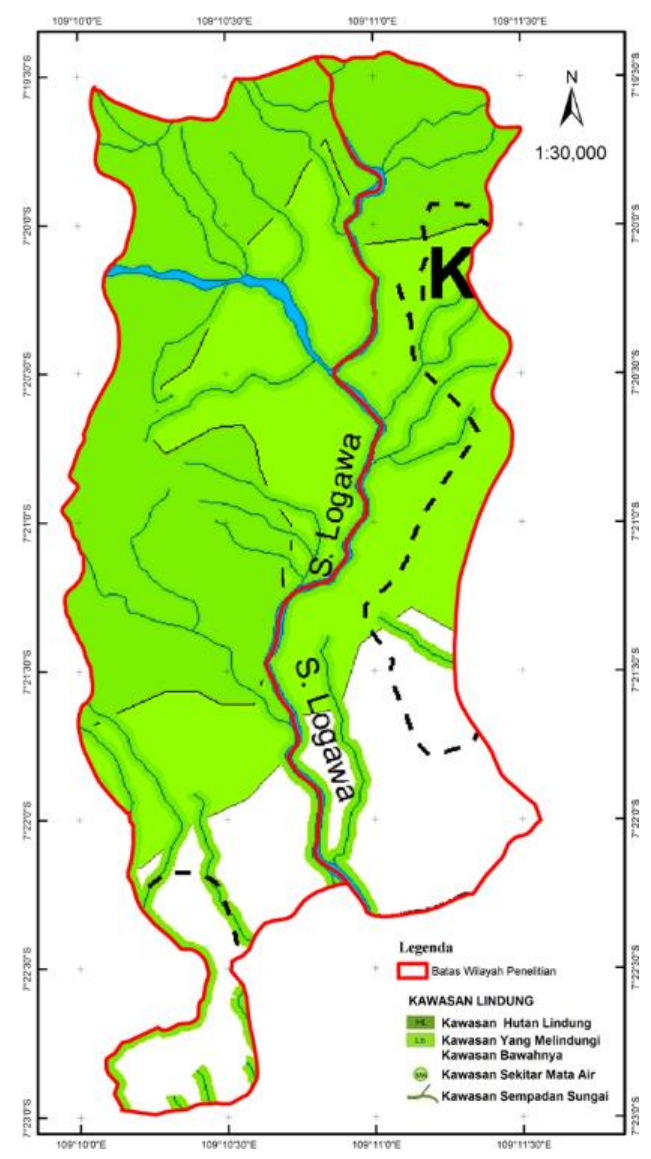

Gambar 1. Olahan Peta Tematik RTRW Kabupaten Banyumas 2011-2031 Peta Kawasan Lindung 


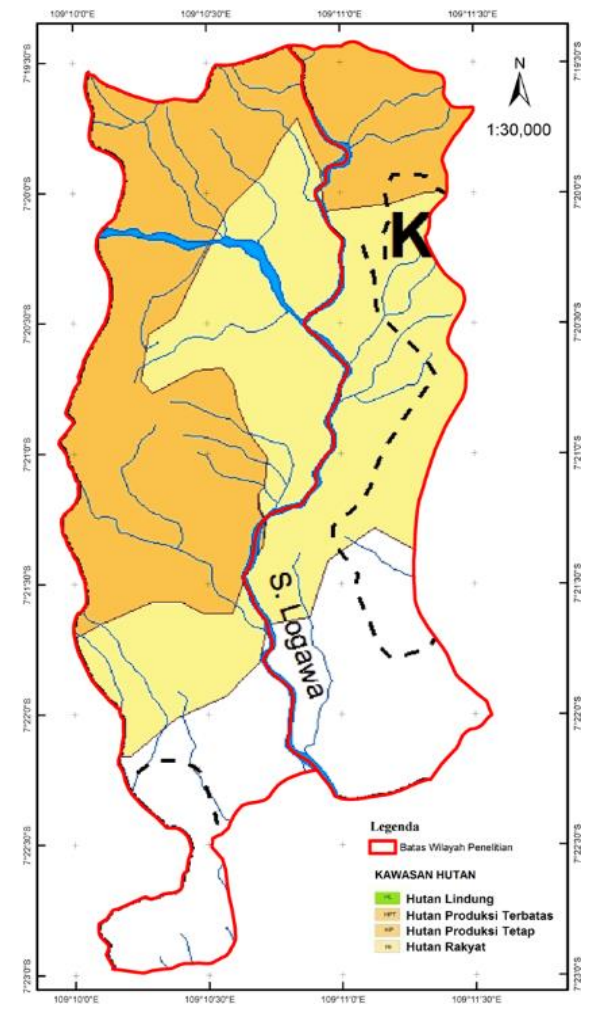

Gambar 2. Olahan Peta Tematik RTRW Kabupaten Banyumas 2011-2031 Peta Kawasan Hutan

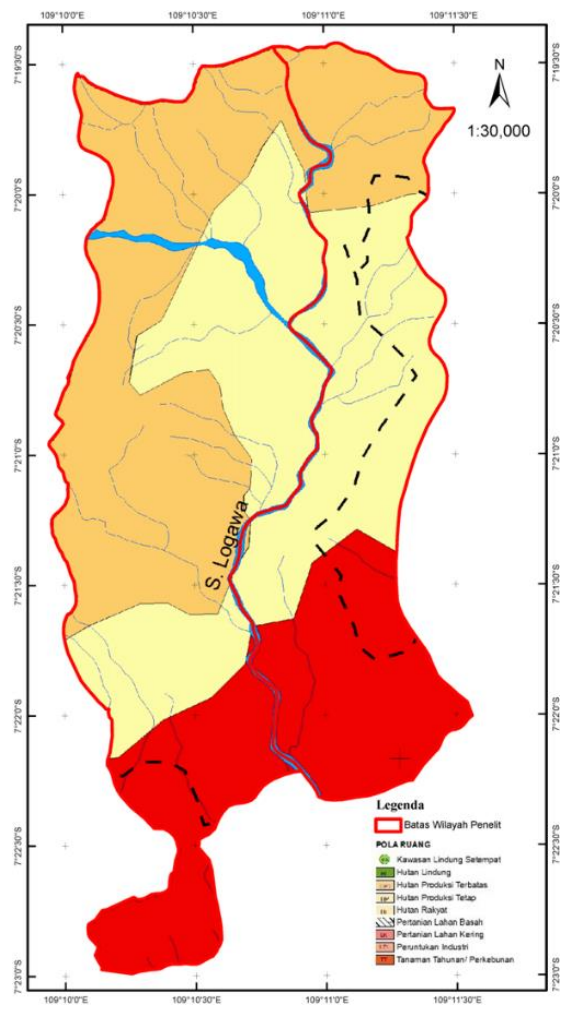

Gambar 3. Olahan Peta Tematik RTRW Kabupaten Banyumas 2011-2031 Peta Pola Ruang 
Dua sektor yang menyumbangkan peran pada kerusakan hulu DAS Serayu lewat perubahan kebijakan tata ruang provinsi adalah sektor pertanian, dengan komoditas tanaman kentang dan sektor pertambangan. Dua sektor ini salah satunya berada dalam lini utama stakeholder pengelola DAS, yaitu sektor pertanian, dalam rentang kelola Kementerian Pertanian. Sektor pertanian menjadi pemanfaat terbesar DAS secara langsung karena kebutuhannya yang besar atas lahan budidaya tanaman kentang. Sektor kedua yang berperan pada kerusakan ekosistem hulu DAS Serayu adalah pertambangan, lewat aktifitas pertambangan batu dan pasir. Sektor pertambangan tidak berada secara langsung dalam lingkar parapihak pengelola DAS, yaitu Kementerian Energi dan Sumber daya Mineral (ESDM).

Dua pihak tersebut yaitu Kementerian Pertanian dan Kementerian ESDM mewakili parapihak yang secara langsung mengelola hulu DAS Serayu dari pihak negara. Perubahan kebijakan penataan ruang pada level provinsi tersebut berdampak pada rusaknya "natural ecosystem" dalam rentang waktu yang panjang, pada lingkup beberapa kabupaten. Interaksi ini menggambarkan secara aktual pendapat Harmiati et al., (2018) bahwa, konsep environmental governance dapat digunakan bagi keperluan memahami dan mengelola hubungan timbal balik antara sistem sosial dengan "ekosistem" itu sendiri (natural ecosystem). Dapat diartikan bahwa, dengan mewujudkan environmental governance dalam pengelolaan DAS sebenarnya sangat erat berkaitan dengan pemanfaatan DAS itu sendiri secara berkelanjutan, dalam jangka panjang.

Penghubung lain untuk memahami kegagalan pengelolaan DAS di Indonesia dan kerusakan ekosistem DAS adalah pengelolaan DAS Citanduy yang sejak tahun 1981 telah menjadi model pemerintah Indonesia untuk mengelola DAS. Poin penting penyebab kegagalan pengelolaan DAS Citanduy disampaikan Dharmawan (2005) dengan dua skenario teori kegagalan, yang membawa pada pengelolaan DAS Citanduy yang buruk. Kegagalan pertama, terjadi pada "ruang negara" dalam aspek penataan administratif, adanya egosentrisme kewilayahan dan penguasaan sumber daya alam. Tiga hal tersebut membuat "tidak terbentuknya tata-pemerintahan lingkungan yang baik". Berkaitan dengan kegagalan di "ruang negara" ini juga dapat ditemukan konflik kepentingan lintas wilayah dan konflik para pemangku kepentingan, koordinasi dan administrasi yang tidak terlaksana dengan baik. Kegagalan kedua, terjadi pada "ruang masyarakat sipil". Kegagalan pada "ruang masyarakat sipil" ini terjadi karena tidak terbentuknya kelembagaan dan jejaring aktor non-negara dari para pihak pengelola sumber daya DAS. Terorganisasinya masyarakat sipil dan terbentuknya jejaring sangat penting untuk menjadi kekuatan penyeimbang aparatus negara untuk bersama-sama mengelola DAS. Pengelolaan DAS secara partisipatif membutuhkan elemen sipil yang kuat agar semangat desentralisasi dan pengelolaan DAS dengan perencanaan bottom-up dapat berjalan.

Dampak lanjutan dari kegagalan pengelolaan DAS Citanduy disajikan Dharmawan et al. (2004) bahwa bersamaan dengan perubahan penggunaan lahan di DAS Citanduy, ada indikasi terjasi proses penurunan kuantitas dan kualitas sumber daya alam dan degradasi lingkungan. Tahap berikutnya kemudian, secara sosiologis indikasi degradasi lingkungan tersebut mengakibatkan perubahan-perubahan sosial pada masyarakat DAS tempatan. Perubahan yang dimaksud berupa perubahan kelembagaan yang mengindikasikan bahwa kelembagaan-kelembagaan dan hubungan antar kelembagaan masyarakat DAS Citanduy tidak lagi berkelanjutan (institutional unsustainability). Dapat ditarik kesimpulan bahwa, pengelolaan DAS yang gagal dapat mempengaruhi perubahan sistem sosial pada masyarakat DAS. Dua contoh kegagalan dalam pengelolaan DAS tersebut menggambarkan bahwa tata pemerintahan yang peka terhadap kelestarian lingkungan hidup, utamanya DAS tidak terbentuk.

Pengelolaan DAS di Indonesia mengadopsi pendapat Elinor Ostrom tentang pengelolaan sumber daya alam. Ostrom $(1990,2008)$ berpendapat bahwa untuk mengelola 


\section{Pengelolaan Hulu Sub-DAS Logawa dalam Perda Penataan Ruang Kabupaten Banyumas}

sumber daya yang berkelanjutan delapan prinsip bisa diterapkan yaitu: (1) membuat batas yang jelas pada kumpulan sumber daya alam yang akan dikelola; (2) membuat perhitungan perbandingan benefit dan cost, (3) Ada aksi-aksi kolektif yang dibangun; (4) ada monitoring bersama; (5) ada sanksi atas pelanggaran kesepakatan yang bersama-sama dirumuskan; (6) ada mekanisme resolusi konflik; (7) diminimalkannya hak-hak preogatif individual untuk mengatur; dan (8) membuat analisis bagi kumpulan sumber daya yang berukuran besar dan tersebar luas, analisis ini hingga lapisan pemanfaat terkecil. Delapan prinsip tersebut dianggap masih relevan digunakan untuk mengelola sumber daya alam yang bersifat milik bersama hingga masa yang akan datang.

Slamet (2015) berpendapat bahwa kegagalan pegiat pengelolaan DAS dalam mengadopsi pandangan Ostrom untuk mengelola DAS di Indonesia terjadi karena beberapa aspek. Aspek pertama, bahwa para pihak yang terlibat dalam pengelolaan DAS, sebagian besar tidak mempunyai komitmen dan kompetensi yang cukup terhadap pengelolaan DAS. Aspek kedua, forum DAS belum bisa memenuhi delapan prinsip yang diajukan Ostrom sepenuhnya. Banyak kegagalan yang diungkapkan dalam pengelolaan DAS, namun berbagai pihak saat ini masih terlibat aktif dalam mendorong pengelolaan DAS sebagai kumpulan sumber daya alam milik bersama. Pengelolaan tersebut dilakukan pada DAS sebagai multi komponen atau pada salah satu komponen saja, yaitu ekosistem hutan. Tutupan lahan hutan ini berelasi langsung dengan permasalahan pengelolaan DAS, contohnya adalah aksi-aksi kolektif dalam (Nursidah et al., 2012).

Dari sudut pandang politik lingkungan dan kebijakan pengelolaan sumber daya alam Pasandaran et al. (2010) melihat pengelolaan DAS adalah nyata sebagai sebuah persoalan politik sumber daya alam. Lebih lanjut menurutnya persoalan ini adalah ajang kontestasi politik investasi yang bersifat eksploitatif dalam pengelolaan kawasan hutan. Pada hulu Sub-DAS Logawa, lewat peta tematik kawasan hutan RTRW Kabupaten Banyumas diketahui sebagian besar wilayah hulu Sub-DAS Logawa tersebut adalah wilayah hutan produksi PT. Perhutani dan wilayah hutan rakyat. Sebagian wilayah yang berstatus hutan produksi tersebut berada dalam wilayah pengelolaan langsung Pt. Perhutani. Pada wilayah ini masyarakat memiliki sangat sedikit akses dan kontrol pada pengelolaannya secara langsung. Pemerintah Kabupaten Banyumas memiliki akses dan peran yang lebih besar untuk dapat mempengaruhi penatakelolaan dalam dalam daur produksi hutan tersebut.

Bagi Pemerintah Kabupaten, otonomi daerah dan potensi sumber daya alam DAS dapat diartikan sebagai aset daerah untuk kemajuan dan kesejahteraan masyarakatnya. Menjaga aset daerah berupa ekosistem DAS yang sehat dapat dilakukan dengan mengambil peran lewat menyusun kebijakan pengelolaan DAS yang berkelanjutan di wilayahnya. Mengelola DAS dapat diartikan sebagai menjaga aset lingkungan hidup yang baik, dengan kaidah-kaidah ekologis yang layak dan berkesinambungan serta dalam ambang batas kemampuan pulih ekosistem tersebut. Benefit yang didapat dengan penataan yang dilakukan akan langsung dirasakan manfaatnya oleh masyarakat Kabupaten Banyumas, terutama Kota Purwokerto dan sekitarnya. Hal ini dimungkinkan, karena SubDAS Logawa seluruh alirannya berada dalam wilayah administrasi Kabupaten Banyumas.

Dengan menerapkan manajemen pengelolaan berbasis DAS bagi perencanaan pengembangan wilayah hulu sungai, diharapkan lebih selaras dan terbentuk secara berkesinambungan. Dari perspektif pengelolaan ekosistem sungai, Omernik \& Bailey (1997) berpendapat bahwa pendekatan pengelolaan wilayah dan sumber daya alam DAS sudah memperhatikan pola ruang serta hubungan dengan masyarakat dan komponen biotik dan abiotik dalam sebuah wilayah. Sedangkan dari perspektif kebijakan publik, Handayani (2013) berpendapat bahwa dengan mempergunakan kebijakan DAS ada kemudahan akan tersedianya pilihan-pilihan. Lebih lengkapnya Handayani menyebutkan ada tiga aspek dalam pengelolaan DAS, pertama ada keputusan (kebijakan), kedua adanya penetapan 
maksud dan tujuan, ketiga ada batasan-batasan ruang lingkup dan tersedianya pilihanpilihan alternatif bagi pencapaian tujuan pengelolaan DAS.

Saat ini, untuk memahami kebijakan Pemerintah Kabupaten Banyumas serta penatakelolaan hulu Sub-DAS Logawa lewat RTRW 2011-2031 yang dapat dilakukan adalah dengan: (1) mengidentifikasi posisi hulu Sub-DAS Logawa dalam peta tematik RTRW Kabupaten Banyumas; (2) memahami fungsi-fungsi wilayah dimana posisi hulu SubDAS Logawa tersebut berada; (3) menafsirkan peruntukan wilayah tersebut sesuai aturan dan ketentuan RTRW 2011-2031; (4) membuat analisis interaksi wilayah tersebut dengan wilayah lain, dan arah pengembangannya dalam pembangunan daerah. Tidak ada kebijakan tentang pelestarian DAS secara harfiah dalam dokumen tersebut, khususnya bagi hulu Sub-DAS Logawa.

Meminjam paradigma kebijakan klasik, Dye (2017) menyatakan bahwa kebijakan adalah, sesuatu yang "telah diatur" atau bahkan "tidak diatur sekalipun" oleh pemerintah. Maka, tidak adanya kebijakan secara spesifik yang mengatur DAS di Kabupaten Banyumas, termasuk tak adanya kebijakan khusus bagi hulu Sub-DAS Logawa, tetap dapat disebut sebagai sebuah "policy". Dari sudut pandang politik lingkungan ketiadaan regulasi dan kebijakan (policy) atas DAS ini dapat dilihat dengan dua cara pandang. Secara legal, kondisi ini tidak menyalahi aturan perundangan, karena aturan perundangan pada tingkat nasional tidak mewajibkan pemerintah daerah kabupaten untuk menyusun peraturan daerah pengelolaan daerah aliran sungai. Namun, dari sisi political attitude, tidak adanya Perda DAS Kabupaten Banyumas, khususnya bagi hulu Sub-DAS Logawa dapat diartikan sebagai diabaikannya peran krusial ekosistem hulu DAS.

Bersamaan dengan era dan semangat desentralisasi yang menjunjung tinggi partisipasi dan peran para pihak, pemerintah dapat memetakan para pihak pengelola DAS di Kabupaten Banyumas khususnya di hulu Sub-DAS Logawa untuk ikut serta dalam menyusun tata kelola dan kebijakan yang sesuai dengan kondisi dan permasalahan dasar DAS. Hal ini juga dapat menjadi pintu masuk bagi menyeimbangkan peran mereka dalam pengelolaan DAS. Sistem tata-pemerintahan baru dalam era otonomi daerah diharapkan dapat responsif terhadap permasalahan lingkungan hidup dan menerapkan good environmental governance. Menurut Work (2001) Sistem tata-pemerintahan yang baik memastikan bekerjanya proses-proses politik, sosial dan ekonomi yang berbasiskan kesepakatan-kesepakatan, kesepahaman-kesepahaman, saling-pengertian (broad consensus) dalam masyarakat, dimana aspirasi semua pihak tertampung dalam perumusan kebijakan dan alokasi sumber daya pembangunan, termasuk golongan termiskin dan kaum perempuan.

Bentuk tata-pemerintahan yang baru ini berlandaskan kemitraan dari tiga pihak yang saling berbeda yaitu negara, masyarakat sipil dan swasta. Para pihak tersebut tentu mempunyai watak, kepentingan dan orientasi berbeda dalam pengelolaan DAS. Selanjutnya dalam sistem tata-pemerintahan yang berbasis kemitraan tersebut menurut Dharmawan (2005) di dalamnya dapat dibangun kesepakatan dan konsensus mewakili ideologi politik dan ekonomi yang saling berlawanan pandangan tersebut. Berkaitan dengan peran negara, maka paradigma Good Environmental Governance saat ini didorong menjadi arus utama dalam pengelolaan lingkungan hidup, termasuk DAS di dalamnya. Purniawati et al. (2020) melihat hal tersebut sebagai sebuah kerangka berfikir bagi pengelolaan negara dalam rangka pengelolaan lingkungan hidup, melalui interaksi dengan rakyatnya.

Handayani (2013) mengamati pengelolaan DAS dari sistem administrasi pembangunan. Dinyatakan bahwa, akar persoalan kerusakan lingkungan adalah karena kegagalan bekerjanya natural resources bersama dengan environmental governance system. Keduanya ada untuk mendorong proses-proses pertukaran ekologis secara efektif, efisien dan berkeadilan. Menurutnya ada "ruang-ruang" berbeda namun saling 
terikat/terkait. Ruang tersebut adalah "ruang human system" dan "ruang bagi non-human system" di kawasan DAS. Selanjutnya menurut Handayani, kegagalan tata-pemerintahan lingkungan terlihat dari tidak konsitennya regulasi antar daerah dalam menata kawasan DAS. Hal tersebut sebenarnya juga terjadi karena karakter DAS sebagai ekosistem yang keberadaannya seringkali lintas administrasi wilayah dan kewenangan. Namun, kegagalan yang berulang-ulang tersebut kemudian menjadi kegagalan keseluruhan sistem tatapemerintahan lingkungan. Pada kemudian hari hal ini dapat dikenali sebagai munculnya krisis ekologi yang banyak terjadi dewasa ini. Dengan mendekati permasalahan pengelolaan DAS dari sudut pandang administrasi pembangunan dan tata-pemerintahan lingkungan, maka Handayani (2013) berpendapat bahwa upaya perbaikan lingkungan (sistem ekologi) DAS tidak dapat dilakukan tanpa mengandalkan perbaikan kelembagaan dan tata-pemerintahan untuk membantu proses regenerasi DAS.

Imperial \& Hennessey (2000) berpendapat bahwa pengelolaan DAS sebenarnya lebih banyak berkaitan dengan "governance" (tata pemerintahan), yakni melibatkan berbagai jaringan kelembagaan. Keduanya menyimpulkan bahwa pada dasarnya, pengelolaan DAS berkisar pada dua hal, masalah sains dan desain kebijakan yang efektif. Wilayah hulu SubDAS Logawa adalah wilayah dengan fungsi yang sangat penting, dan sebenarnya telah diidentifikasi dalam RTRW 2011-2031 sebagai kawasan lindung lintas wilayah. Regulasi yang sesuai dapat menjaga agar hulu Sub-DAS Logawa tidak terdegradasi ekositemnya. Hal tersebut sama halnya dengan memastikan potensi dan aset lingkungan hidup yang lestari, bagi pengembangan kesejahteraan masyarakat Kabupaten Banyumas untuk masa yang akan datang.

\section{Kesimpulan}

Hulu Sub-DAS Logawa diatur Perda RTRW Kabupaten Banyumas sebagai kawasan lindung. Tidak disebutkan batasan minimal luas lahan hutan yang diharuskan bagi kawasan lindung ekosistem hulu DAS. Pada bagian indikasi program, wilayah penelitian ditetapkan sebagai wilayah rencana pengembangan wisata sungai dan wilayah pengembangan pembangkit tenaga listrik. Ekosistem hulu Sub-DAS Logawa membutuhkan sebuah kebijakan dengan orientasi menjaga kelestarian serta keberlanjutan pengelolaan DAS dalam jangka panjang.

Relasi antara "human ecosystem" dan "natural ecosystem" dalam studi ini diharapkan dapat menggambarkan kondisi hulu Sub-DAS di Kabupaten Banyumas bagi disiplin ilmu perencanaan dan pengembangan wilayah serta manajemen lingkungan. Lesson learn dari pelaksanaan penelitian adalah, bahwa manajemen lingkungan hulu DAS dan upaya untuk menciptakan good environmental governance tidak dapat dilepaskaitkan begitu saja, baik dalam tataran praksisnya maupun dalam kajian.

\section{Ucapan Terima Kasih}

Publikasi penelitian ini merupakan bagian dari tesis yang diajukan pada Program Studi Magister Ilmu Lingkungan, Program Pasca Sarjana, Universitas Jenderal Soedirman, Purwokerto tahun 2021. Terimakasih kepada para pembimbing, koordinator program studi dan para penelaah yang telah memberikan kritik dan saran.

\section{Daftar Pustaka}

Dharmawan, A. H., Krisnamurthi, B., Tanjung, D., Tonny, F., Prasetyo, L. B., Fausia, L., Prasodjo, N. W., Suharno, S., Indaryanti, Y., \& Mardiyaningsih, D. I. (2004). Desentralisasi pengelolaan dan sistem tata - 
pemerintahan sumberdaya alam Daerah Aliran Sungai Citanduy (Project Working Paper Series No. 01). Bogor.

Dharmawan, A. H. (2005). Analisis politik ekologi sistem tata pernerintahan sumberdaya alam common pool resources Daerah Aliran Sungai Citanduy (Pembaharuan tata pemerintahan lingkungan (menciptakan ruang kemitraan negara-masyarakat sipil-swasta). Bogor.

Dinas Lingkungan Hidup Kabupaten Banyumas. (2009). Status lingkungan hidup daerah Kabupaten Banyumas tahun 2009. Kabupaten Banyumas: Dinas Lingkungan Hidup Kabupaten Banyumas.

Dye, T. R. (2017). Understanding public policy (15th Ed). Florida State University Pearson.

Ethika, D.N.; Ris, Hadi Purwanto; Senawi, Senawi; Masyhuri, M. (2014a). Kontribusi usaha hutan rakyat di bagian hulu Sub Das Logawa Kabupaten Banyumas (Kajian kelayakan usaha kayu sengon di Kecamatan Kedungbanteng). Jurnal Agrin Fakultas Pertanian Unsoed, 18(2). doi:10.20884/1.agrin.2014.18.2.217.

Ethika, D.N.; Ris, Hadi Purwanto; Senawi, Senawi; Masyhuri, M. (2014b). Peranan Petani terhadap strategi pembangunan hutan rakyat di bagian Hulu Sub Das Logawa di Kabupaten Banyumas Jawa Tengah. Jurnal Manusia dan Lingkungan, 21(3), 377-385. doi:10.22146/jml.18566.

Ethika, D. N. (2015). Strategi pembangunan hutan rakyat Sub Das Logawa di Kabupaten Banyumas. Universitas Gadjah Mada.

Handayani, I. G. A. K. R. (2013). Urgensi peraturan daerah pengelolaan Daerah Aliran Sungai Bengawan Solo dalam rangka penguatan fungsi lingkungan hidup dan good governance. Jurnal Hukum Ius Quia Iustum, 20, 255-277. doi:10.20885/iustum.vol20.iss2.art5.

Harmiati, H., Aprianty, H., Supriyono, S., Sulistyo, B., Triyanto, D., \& Alexsander, A. (2018). Implementasi good enviromental governance dalam pengelolaan daerah aliran sungai (DAS) Bengkulu. Jurnal Ilmu Pemerintahan : Kajian Ilmu Pemerintahan dan Politik Daerah, 3, 136-148. doi: 10.24905/jip.3.2.2018.136148.

Imperial, M. T., \& Hennessey, T. (2000). Environmental governance in watersheds: The role of collaboration. Retrieved from: https://hdl.handle.net/10535/1046.

Irawadi, I. (2014). Pengembangan konsep manajemen aset kelembagaan sumberdaya air pada Sub Daerah Aliran Sungai Logawa. Universitas Gajah Mada.

Kementerian Kehutanan. (2009). Peraturan Menteri Kehutanan Nomor 39 Tahun 2009 tentang pedoman penyusunan rencana pengelolaan DAS Terpadu. Jakarta: Kementerian Kehutanan.

Lestari, W. (2004). The fish community of a tropical organically polluted river: A case study of the Logawa River, Central Java, Indonesia. Cuvillier Verlag Göttingen, Germany.

Likens, G. E., \& Bormann, F. H. (1974). Linkages between Terrestrial and Aquatic Ecosystems. BioScience, 24(8), 447-456. doi:10.2307/1296852.

Nk, R., Fauzi, M., Rahmawati, Firmansyah, R., Fathoni, A., \& Hatmoko, W. (2013). Neraca ketersediaan air permukaan dan kebutuhan air pada wilayah sungai di Indonesia. In Kolokium Hasil Penelitian dan Pengembangan Sumber Daya Air. Bandung: Pusat Litbang Sumber Daya Air.

Nugroho, S. P. (2009). Perubahan watak hidrologi sungai-sungai bagian hulu di Jawa. Jurnal Air Indonesia, 5(2), 112-118. doi:10.29122/jai.v5i2.2439.

Nursidah, Nugroho, B., Darusman, D., Rusdiana, O., \& Rasyid, Y. (2012). Pengembangan institusi untuk membangun aksi kolektif lokal dalam pengelolaan hutan kawasan lindung SWP DAS Arau, Sumatera Barat. Jurnal Manajemen Hutan Tropika, 18(1), 18-30. doi:10.7226/jtfm.18.1.18.

Omernik, J. M.; Bailey, R. G. (1997). Distinguishing between watersheds and ecoregions. American Water Resources Association, 33(5), 935-949.

Ostrom, E. (1990). Governing the commons institutions: The evolution of institution for collective action. New York: Cambrige University Press.

Ostrom, Elinor. (2008). The challenge of common-pool resources. Environment: Science and Policy for Sustainable Development, 50(4), 8-21. doi:10.3200/ENVT.50.4.8-21.

Pemerintah Kabupaten Banjarnegara. (2013). Peraturan Daerah Kabupaten Banjarnegara Nomor 4 Tahun 2013 Tentang Pengelolaan Daerah aliran Sungai. Banjarnegara: Pemerintah Kabupaten Banjarnegara.

Pemerintah Kabupaten Banyumas. (2011). Peraturan Daerah Kabupaten Banyumas Nomor 10 Tahun 2011 tentang rencana tata ruang wilayah Kabupaten Banyumas 2011-2031. Banyumas: Pemerintah Kabupaten 


\section{Pengelolaan Hulu Sub-DAS Logawa dalam Perda Penataan Ruang Kabupaten Banyumas}

Banyumas.

Pemerintah Provinsi Jawa Tengah. (2014). Peraturan Daerah Provinsi Jawa Tengah Nomor 15 Tahun 2014 tentang daerah aliran sungai di wilayah Provinsi Jawa Tengah. Semarang: Pemerintah Provinsi Jawa Tengah.

Pemerintah Republik Indonesia. (2004). Undang-Undang Nomor 7 Tahun 2004 tentang Sumber Daya Air. Jakarta.

Pemerintah Republik Indonesia. (2012). Peraturan Pemerintah Nomor 37 Tahun 2012 tentang pengelolaan DAS (2012). Jakarta.

Purniawati, P., Kasana, N., \& Rodiyah, R. (2020). Good environmental governance in indonesia (perspective of environmental protection and management). The Indonesian Journal of International Clinical Legal Education, 2(1), 43-56. doi:10.15294/ijicle.v2i1.37328.

Saridewi, T., Hadi, S., Fauzi, A., \& Rusastra, I. (2014). Penataan ruang Daerah Aliran Sungai Ciliwung dengan pendekatan kelembagaan dalam perspektif pemantapan pengelolaan usahatani. Forum Penelitian Agro Ekonomi, 32(2), 87. doi:10.21082/fae.v32n2.2014.87-102.

Slamet, B. (2015). Kegagalan collective action dalam pengelolaan Daerah Aliran Sungai (studi kasus kelembagaan forum DAS). 1-17.doi:10.13140/RG.2.1.1331.9523.

Suradisastra, K., Pasaribu, S. M., Sayaka, B., Dariah, A., Las, I., Haryono, H., Pasandaran, E. (2010). Membalik kecenderungan degradasi sumber daya lahan dan air. Bogor: IPB Press.

Susanti, Y.; Syafrudin, Syafrudin; Helmi, M. (2020). Analisa perubahan penggunaan lahan di Daerah Aliran Sungai Serayu Hulu dengan penginderaan jauh dan sistem informasi geografis. BIOEDUKASI: Jurnal Pendidikan Biologi, 13(1), 23-30.

Suwarno, Suwarno; Sutomo, Sutomo; Setiawan, E. (2017). Pemetaan bahaya erosi di Sub-Daerah Aliran Sungai Logawa Kabupaten Banyumas dengan sistem informasi geografis. Prosiding Seminar Nasional Penerapan Ilmu Pengetahuan dan Teknologi (pp. 159-164). Pontianak.

Wicaksono, P. A., Somantri, M., \& Windarto, D. (2013). Sistem Informasi Potensi dan Analisa Perencanaan Pembangkit Listrik Tenaga Mikrohidro (PLTMH) dI Indonesia menggunakan pemrograman PHP. Transient: Jurnal Ilmiah Teknik Elektro, 2(2).

Wijaya, W., Windarto, J., \& Karnoto, K. (2012). Analisa perencanaan pembangkit listrik tenaga mini hidro di Sungai Logawa Kecamatan Kedungbanteng Kabupaten Banyumas. Transient: Jurnal Ilmiah Teknik Elektro, 1(3).

Work, R. (2001). The role of participation and partnership in decentralised governance: $A$ brief synthesis of policy lessons and recommendations of nine country case studies on service delivery for the poor. New York. 